\title{
Testing of potential biomarkers of cerebral ischemia and vasospasm in patients with cerebral aneurysm surgery
}

BY JELENA RADONIC, DUNJA ROGIC, RADOVAN RADONIC, TAMARA MURSELOVIC, VASILIJE STAMBOLIJA, JADRANKA KATANCIC, MARIN LOZIC, LJILJANA POPOVIC

\section{Abstract}

Biomarkers for the prediction of vasospasm and delayed cerebral ischemia in patients with a ruptured cerebral aneurysm could be helpful.

In this prospective clinical study, endothelin-1, lactate, $\mathrm{pCO}_{2}$, and $\mathrm{pO}_{2}$ were measured in arterial and internal jugular vein blood before, during and after surgical treatment of a cerebral aneurysm, and were tested as potential predictors of neurologic outcome in patients.

Forty-one patients were enrolled in the study, 23 of them were operated on after aneurismal rupture with development of subarachnoid hemorrhage (SAH) and 18 patients were operated on for a nonruptured aneurysm.

All of the involved patients survived. There was no difference in neurologic outcome between those operated on with a ruptured or nonruptured aneurysm.

Endothelin-1 and lactate concentrations as well as $\mathrm{pO}_{2}$ and $\mathrm{pCO}_{2}$ from arterial and venous blood samples and their venoarterial difference did not differ between groups with and without an aneurismal rupture. Venoarterial difference of endothelin-1 concentrations on the day after surgery significantly differed between the groups with favorable and nonfavorable neurologic outcome. Other variables did not show a statistically significant difference.

Significant correlation was found between endothelin-1 and lactate concentrations, suggesting involvement of the same pathophysiological process.

Another interesting finding was lower arterial and venous $\mathrm{pCO}_{2}$ in patients with lower 
initial Glasgow Coma Scale (GCS) score and higher Hunt Hess score in the phase after extubation.

We can conclude that the measured biochemical parameters did not show sufficient predictive power to be useful for prediction of cerebral vasospasm and neurologic outcome in everyday clinical practice. However, some correlations that do exist between them suggest involvement of the same pathophysiological process.

Key words: cerebral aneurysm, neurosurgery, endothelin-1, biomarkers, delayed cerebral ischemia

\section{Introduction}

Subarachnoid hemorrhage (SAH) is a dramatic event with a rapid rise in intracranial pressure. Severe headache, nausea, vomiting, double vision, and nuchal rigidity, eventually accompanied by seizures are the usual clinical presentation. Furthermore, loss of consciousness and even death can occur. Signs of meningeal irritation are often positive. Incidence of SAH is 7-13/100000 of population per year. (1-5) Incidence of cerebral aneurysm is around 1.8 to $2 \%$. (6-8) Mortality from a ruptured cerebral aneurysm and development of SAH is rather high, around 50\%. (9) Approximately $10 \%$ of patients die before reaching hospital, $25 \%$ die in the first 24 hours, and another $25 \%$ die in the first month after rupture, usually due to recurrent bleeding. (10) Risk of recurrent bleeding in the first 24 hours after aneurismal rupture is between 2.6 to $4 \%$. $(11,12)$ The majority (73\%) of recurrent bleeding occurs in the first 3 days after rupture. (13)

In addition, patients with SAH can also develop delayed cerebral ischemia. It is explained mainly by the development of cerebral vasospasm. Clinical manifestations of these events are impaired consciousness and focal neurologic deficits.

Literature data about the incidence of cerebral vasospasm in patients with ruptured cerebral aneurysm and SAH vary in the range of 1.5 to $91 \%$ which demonstrates the diagnostic difficulties when different methods and different definitions are used. $(14,15)$ In general the incidence could be considered around 20-30\%. (16) An up-to-date uniform method for definition and classification of cerebral vasospasm has not been established yet. (17)

Cerebral angiography could be chosen as the gold standard for the recognition of cerebral vasospasm, but it provides insight into spasm of large arteries only and cannot show the state of the microcirculation. An association between diffuse angiographic vasospasm and patient outcome has not been found. (15) Repeated angiography for vasospasm monitoring in patients with SAH is not appropriate. Some authors suggest serial exams using transcranial Doppler to detect development of cerebral vasospasm. $(18,19)$ However, a higher velocity of blood flow is not always seen in patients with cerebral vasospasm.

Surprisingly, reduced blood flow can be found in some patients, compromising the transcranial Doppler as a unique method in diagnosing and monitoring of cerebral vasospasm. (17) 
Despite its imperfection, clinical assessment is often used as a method for estimation of the presence of cerebral vasospasm. (20) Clinical judgement has been shown to be superior in the prediction of cerebral ischemia and its consequences compared to angiography or transcranial doppler (TCD) defined cerebral vasospasm. (21) Subjectivity and difficulties in the clinical assessment of consciousness in sedate and anesthetized patients, as well as low sensitivity for subtle changes in consciousness remain the main weaknesses of this method. $(21,22)$

The main goal of surgical intervention is prevention of recurrent bleeding. Cerebral vasospasm is usually not present in the first three days after the aneurismal rupture. It develops typically between the $4^{\text {th }}$ and $14^{\text {th }}$ day after rupture. (9) According to some authorities, surgical intervention should not be performed in the presence of vasospasm, instead, it should be either done earlier, in the first three days after the rupture, or it should be delayed for two weeks after the rupture. It could be supposed that cerebral vasospasm is already resolved two weeks after the rupture.

Additional biochemical markers of cerebral vasospasm and cerebral ischemia could be helpful in routine clinical practice. In the case of cerebral vasospasm, hyperventilation during surgical intervention should be avoided. According to some authors, blood oximetry of samples obtained from the jugular bulb during the operation can provide information about the presence of cerebral ischemia. (23-25) Lower oxygen saturation of hemoglobin is associated with higher oxygen release in ischemic areas of the brain, which are developed by vasospasm.

Lactate is a product of anaerobic metabolism and is a well known marker of tissue ischemia. Measurements of lactate concentrations in the jugular vein and comparison with concentrations in arterial blood could potentially provide an insight into the amount of energy produced in the brain by anaerobic metabolism. $(26,27)$

Pathogenesis of cerebral vasospasm is not completely clear. It is supposed that degraded products of blood induce vasoconstriction of arteries in the cerebrospinal space.

Endothelin released from the intimal layer of blood vessels is a potent vasoconstrictor. Several experimental studies as well as some clinical studies demonstrated its potential role in the development of cerebral vasospasm. (28-31) Still, there are several studies which could not confirm this finding. (32-34)

In our study, concentrations of endothelin-1, lactate, and partial pressures of oxygen $\left(\mathrm{PO}_{2}\right)$ and carbon dioxide $\left(\mathrm{pCO}_{2}\right)$ were tested in arterial and jugular vein blood as predictors of outcome and potential markers of cerebral vasospasm and ischemia in patients who underwent operation of cerebral aneurysm.

\section{Patients and methods}

The study was approved by the Clinical Hospital Centre Zagreb Ethics Committee. Patients who underwent neurosurgical operation of a cerebral artery aneurysm were considered eligible for enrollment in this prospective study. Inclusion criteria were: 
inform consent signed by the patient or close relative and availability of the investigator during the operative procedure. The patients were divided into two groups: group 1 with a ruptured cerebral aneurysm and group 2 with a nonruptured cerebral aneurysm. The latter represent the control group.

For preoperative sedation all patients received midazolam intramuscularly. Thiopental was used in a dose of 3-6 mg/ $\mathrm{kg}$ of body weight and fentanyl in a dose of 0.5-9 ug/ $/ \mathrm{kg}$ for induction of anesthesia and intubation. Muscle relaxants, vecuronium or pancuronium, were given at a dose of 0.1 do $0.15 \mathrm{mg} / \mathrm{kg}$ and recuronium at a dose of 0.6 do $1.2 \mathrm{mg} / \mathrm{kg}$. For maintenance of anesthesia, tiopental and fentanyl drip were used. Target systolic blood pressure, till clamping of aneurysm, was 95-100 $\mathrm{mmHg}$.

After clamping of the aneurysm, reasonable triple $\mathrm{H}$ therapy (hemodilution, hypertension and hypervolemia) was conducted in all patients. Dosage was individualized during the operation by the attending anesthesiologist and in the intensive care unit after the operation. Target hematocrit was 33-38\%, target central venous pressure was 5-12 mmHg, and target systolic blood pressure was 130-200 mmHg.

Continuous intravenous nimodipine was included in the postoperative period if the systolic blood pressure exceeded $140 \mathrm{mmHg}$, and its dosage was titrated until target systolic blood pressures were reached. Maximal dose of nimodipine was $2 \mathrm{mg} / \mathrm{h}$. Normal saline infusion was used to keep patients optimally hydrated or mildly hyperhydrated.

Simultaneous blood samples for laboratory analysis were obtained from the radial artery and from the jugular vein bulbus in all patients. Samples were taken: after induction of anesthesia, before the operation, after opening the dura mater, 5 minutes after clamping of the aneurismal neck, 30 minutes after aneurismal clamping, after postoperative arrival in the intensive care unit, after awakening, after extubation and on the day after the operation. Blood gases and lactate concentrations were measured in all samples. Endothelin-1 concentrations were measured in samples obtained before the beginning of the surgical procedure, during the operation (30 minutes after clamping of the aneurismal neck) and the next morning after the operation.

Neurologic state was followed and recorded using the Hunt Hess scale. State of consciousness was assessed using the Glasgow Coma Scale (GCS), (35-37) before induction of anesthesia, every hour during the first 24 hours after the operation, and daily in the later postoperative period. Evaluation of motoric deficit was performed before the operation, after recovery from general anesthesia and 6 months after the operation. Glasgow Coma Scale of 14 or lower, as well as worsening of motoric deficit, were the main criteria for diagnosis of delayed cerebral ischemia and cerebral vasospasm, after other possible causes were excluded. (38) Investigators who evaluated state of consciousness and motoric deficit were "blind" to the laboratory results.

A modified Marbach-Weil method ("Dade Behring, Dimension Clinical Chemistry System") was used for the measurements of blood lactate concentrations using "Lactic Acid Flex" reagents. $(39,40)$ 
Endothelin-1 concentrations were measured by ELISA method ("Biomedical Assays”).

$\mathrm{PCO}_{2}$ in blood was measured by potentiometry and $\mathrm{PO}_{2}$ in blood by amperometry (GEM Premier 3000).

Functional outcome was measured by modified Rankin scale 6 months after the operation. When Rankin score was 3 or higher, the outcome was classified as poor. (41-43)

Statistical analysis was performed using MedCalc Software version 12.1.3. (Mariakerke, Belgium).

Numerical variables were tested for the normality of distribution using KolmogorovSmirnov test and were presented as mean \pm standard deviation or median (interquartile range) as appropriate. T test was used to compare normally distributed variables, and ANOVA was used to explore the difference among more than two subgroups (Hochberg's test for post hoc analysis). Kruskal-Wallis test was used to explore the difference between more than two variables that were not distributed normally. Nonparametric MannWhitney U-test was used to compare the difference between two subgroups with no normally distributed variables. To compare the difference in proportions, Pearson's $\chi^{2}$ and $\chi^{2}$ for post hoc analysis were used. Fisher's test was used in case of small sample size. To determine the correlation between two continuous variables Spearman's rho test was used. $\mathrm{P}$ value $<0.05$ was considered significant.

\section{Results}

Over a period of two years, 144 patients underwent surgery for a cerebral artery aneurysm. Forty-one consecutive patients from this group were enrolled in the study. The selection depended on the availability of the investigator during the surgical procedure and patients' consent to be included in the study.

There were 30 females (73.2\%) and 11 males (26.8\%). By binominal test, females were significantly more common $(\mathrm{P}=0.003)$.

In 31 patients ( $75.6 \%$ ), the aneurysm was present on one of the cerebral arteries, whereas in 10 (24.4\%) patients, aneurysms were found on more than one artery.

In $23(56.1 \%)$ patients, the operation was performed after aneurismal rupture and development of SAH, while in 18 (43.9\%) patients a nonruptured aneurysm was discovered coincidentally, and the operative procedure was elective.

There was no difference between these two groups according to age, gender, and mean arterial pressure before, during and after the operation (table 1).

Patients with a nonruptured aneurysm awakened significantly earlier after the operation and were extubated earlier than those operated on after aneurysm rupture and SAH development. The amount of thiopental administered during the operation was somewhat larger in the group with SAH but the statistical significance was borderline. Frequency of neurologic deficits did not differ between groups. There was no difference in Glasgow 
outcome scale (GOS) and Rankin outcome scale between these two groups in the postoperative period, as well as 6 months after the operation.

Analysis of blood samples obtained before aneurysm clamping, 5 and 30 minutes after clamping, at arrival to the intensive care unit (ICU) after the operation, at the moment of awakening, at the moment of extubation and the next day after the operation, did not show significant differences in blood gases, lactate and endothelin-1 values between the two groups.There was some statistically significant, but clinically irrelevant, difference in the results of blood gas analysis. Comparison of the groups with favorable and unfavorable outcome for arteriovenous difference in lactate concentration on the day after the operation, showed a higher difference in the group with a unfavorable outcome (table 2). There were also statistically significant differences in $\mathrm{pCO}_{2}$ during the operation and immediately after the operation showing lower $\mathrm{pCO}_{2}$ in the group with an unfavorable neurologic outcome. Other measured parameters did not differ significantly between these two groups.

Several correlations were found using Spearman rho statistical test. There was a clear correlation between venoarterial difference of lactate concentrations in samples obtained 30 minutes after aneurismal clamping and initial GCS and Hunt Hess score. The same correlation was found with almost all GCS scores after general anesthesia, assessed every hour after the operation (table 3).Thus, such a correlation could not be found for absolute lactate concentrations from arterial and venous blood samples. This finding point out that there is higher lactate production, during the operation, in brains of patients with a lower GCS.

Higher venoarterial difference in lactate concentrations before induction of anesthesia was associated with lower initial GCS, as well as with lower GCS 21 hours and 2 days after operation.

Significant correlation was found between the following scores and $\mathrm{pCO}_{2}$ : Hunt Hess before surgery, GCS score before and after the operation and $\mathrm{pCO}_{2}$ in venous and arterial blood samples obtained at the time of extubation and on the morning after the operation (table 3).

$\mathrm{PCO}_{2}$ found in arterial and venous blood before the operation was not in correlation with GCS before and after the operation.

In the entire population of patients operated on for cerebral aneurysm a positive correlation was observed between concentrations of endothelin-1 before the operation and arterial blood lactate before the operation, as well as in samples taken 5 and 30 minutes after clamping of the aneurysm. However, when only observing the group of patients with a ruptured aneurysm, no correlation between endothelin-1 and lactate concentrations was demonstrable (table 4).

The correlation between endothelin-1 concentrations and venoarterial difference of endothelin-1 concentrations and Hunt Hess and GCS scores was not found in all samples. 
No significant correlation between endothelin-1 concentration and $\mathrm{pCO}_{2}$ or $\mathrm{pO}_{2}$ values was found, except for correlation between venoarterial difference in endothelin-1 concentration and $\mathrm{pCO}_{2}$ in venous and arterial blood after the operation, at the time when patients were transferred to the ICU $\left(\mathrm{r}_{\mathrm{S}} \mathrm{0}, 445, \mathrm{P}=0.04\right)$.

There was positive correlation between endotelin-1 concentrations in the jugular vein before the operation and hours until recovery of consciousness from general anesthesia. Patients with higher endotelin-1 needed more time to wake spontaneously.

Positive correlation was also found between the time period in hours from rupture to operation and endothelin-1 concentrations in the jugular vein before patients were operated.

The population of patients operated on 3 or less days after aneurismal rupture had significantly higher endothelin-1 concentrations in the jugular vein before the operation compared to those operated later $\left(\mathrm{r}_{\mathrm{S}}=0,516 ; \mathrm{P}=0,034\right)$. This however was not shown if the population with SAH was analysed.

There is a correlation between lactate concentrations in the vein and artery and the time of extubation (arterial lactate $r_{S}=0,346 ; P=0,029$, venous lactate $r_{S}=0,490 ; P=0,001$ ).

No correlation between GOS and Rankin score and some of measured biochemical parameters was found.

\section{Discussion}

The Eetiology of cerebral ischemia in cerebral aneurysm rupture is multifactorial. Arterial vasospasm is supposed to play the main role, still, impairment of autoregulation of cerebral blood flow, presence or absence of collateral circulation, possible spasm of small vessels, platelets aggregation, as well as negative side effects of angiography and the surgical procedure may also have a significant role. (21,44-48)

It is difficult to estimate the real incidence of cerebral vasospasm due to lack of a uniform definition, adequate diagnostic method and clear understanding of the pathophysiologic mechanism of spasm of cerebral arteries and changes in the microcirculation. Despite all these weaknesses, the clinical definition of cerebral vasospasm is one of the most commonly used. Nevertheless, clinical diagnosis of delayed cerebral ischemia is retrospective and is therefore not useful in clinical practice, where the main goal is to prevent this event. A series of biochemical markers of neuronal degradation products were tested and none of them proved to be a powerful marker of cerebral vasospasm and delayed cerebral ischemia. A palette of them combined is shown to be somewhat more reliable. Since all of them are markers of already developed neuronal damage, detection of mediators of vasoconstriction and ischemia that precede neuronal damage would be of significant interest to guide the treatment and to avoid cerebral damage.

In this study potential biomarkers for detection of cerebral ischemia such as: oxygen 
extraction and production of carbon dioxide and lactate in the brain tissue were tested together with endothelin-1, a peptide which probably plays a role in the development of cerebral vasospasm.

In this study there was no significant difference in endothelin-1 concentrations between the groups of patients operated due to ruptured and nonruptured cerebral aneurysm.

Venoarterial difference in endothelin-1 concentrations differed significantly on the day after the operation between groups of patients with a favorable and unfavorable neurologic outcome. Endothelin-1, analysed in samples before and during the operation of cerebral aneurysm, did not differ significantly between these two groups. When the population of patients, operated in the first 3 days after the aneurismal rupture, was analysed, there was a positive correlation of endothelin-1 levels found in the samples obtained at the time of induction of anesthesia and the time from rupture to operation. These observations show that patients with a ruptured aneurysm and SAH experience a rise of endothelin-1 in the first several days, which corresponds to the usual delay for cerebral vasospasm to develop.

Interesting, is also the finding of a positive correlation between endothelin-1 concentrations before surgery and blood lactate in serial samples later. This indicates that endothelin-1 and lactate are both involved in the same pathophysiological process of delayed cerebral ischemia, which can determine the patient's outcome. The most logical explanation is that there is higher lactate production in ischemic brain tissue. Brain ischemia is provoked by vasospasm which could be mediated by endothelin-1, a potent vasoconstrictor. Still, other explanations are also possible.

A negative correlation between GCS before the operation and venoarterial difference in lactate concentration at the same time, suggests a higher lactate production in the brain of patients with a lower GCS. Positive correlation of endothelin-1 levels measured at the time of induction of anesthesia and the time period from rupture to operation was observed in the population of patients operated on in the first 3 days after the aneurismal rupture. This was no longer present if all patients operated on after aneurismal rupture were included. Such an observation is in concordance with current knowledge about endothelin-1 concentrations rising in the first few days after rupture. $(28,49,50)$

At the moment of awakening from general anesthesia, a lower $\mathrm{pCO}_{2}$ in the jugular vein was found in the group of patients operated on after aneurismal rupture compared to the group operated on for a nonruptured cerebral aneurysm. A similar result was observed if the group of patients with supposed cerebral vasospasm and the group without it were compared, yet only with a borderline statistical significance. Also, lower $\mathrm{pCO}_{2}$ was found both in arterial and venous blood in the group of patients operated on after aneurismal rupture in samples obtained at the moment of extubation and on the next day. There is also a clear correlation between lower postoperative GCS and lower $\mathrm{pCO}_{2}$ in arterial and jugular vein blood after the operation. $\mathrm{CO}_{2}$ is a product of aerobic metabolism, so lower $\mathrm{pCO}_{2}$ production in ischemic tissue could be expected. But, other factors such as blood 
flow can theoretically also influence $\mathrm{pCO}_{2}$ in venous blood. Lower arterial and consequently venous $\mathrm{pCO}_{2}$ is best explained by spontaneous higher lung ventilation in these patients. The main question is whether this is a desirable compensatory mechanism or an impairment of optimal regulation. $\mathrm{CO}_{2}$ is a well known cerebral vasodilator whereas hyperventilation leads to cerebral vasoconstriction. Therefore, hyperventilation can prevent development of brain edema, but can also worsen cerebral ischemia. A remaining question is whether mild hyperventilation resulting in lower $\mathrm{pCO}_{2}$ could contribute to the development of cerebral vasospasm and delayed cerebral ischemia. This observation can bring up a question of changing the sedation protocol in patients with SAH to prevent spontaneous hyperventilation. In the case where this is a favorable compensatory mechanism, mild hyperventilation during general anesthesia could be an option. Further studies are needed to clarify these dilemmas.

The study is designed to identify potential biomarkers of cerebral ischemia, which could eventually be used in clinical practice. The number of patients enrolled in the study is big enough to detect a precise and reliable biomarker which is sensitive and specific enough to have significant predictive power. The majority of similar studies that tested biomarkers in patients with SAH had even smaller numbers of patients. The weakness of this study is that the observed patient population was not that severely ill as the other studied populations operated on for cerebral aneurysm with SAH. The lack of the most severe cases, with severe pathophysiologic derangement and unfavorable outcome, can hide potential differences between patients operated on electively and those operated on after aneurismal rupture. The same can be assumed for the potential difference between those with a favorable outcome, without any sequel, and those with some, but in general rather mild,neurologic impairment. In our study, the Hunt Hess score in the observed population of patients with a ruptured aneurysm was low, so a favorable outcome was expected. For example, in the study of Siman et al, the average Hunt Hess score was 2.6 compared to 1.48 in our study. (51) In the study of Mascia et al, 6 of 20 patients had GCS of less than 8. (52) In other words, discrete brain lesions did not cause great pathophysiological derangement which could lead to significant production of potential biomarkers like endothelin-1. Similar could be assumed for concentrations of lactate, since mild regional ischemia cannot produce enough detectable lactate in blood samples. Only significant brain ischemia with significant number of brain cells switched to anaerobic metabolism could result in detectable lactate production, which could be confirmed by measuring the venoarterial difference in blood lactate concentrations. For this purpose, venous samples are obtained from the jugular vein, which contains blood coming directly from the brain.

We can conclude that despite some interesting positive results of statistical tests and possibilities of explaining them according to pathophysiological principles of cerebral vasospasm and ischemia, this study did not demonstrate that lactate, blood gases and endothelin-1, analysed in arterial blood and venous blood coming from the brain, could serve as reliable and useful clinical markers or powerful predictors of delayed cerebral ischemia in everyday clinical practice. 


\section{References}

1. de Rooij NK, Linn FH, van der Plas JA, Algra A, Rinkel GJ. Incidence of subarachnoid haemorrhage: a systematic review with emphasis on region, age, gender and time trends. J Neurol Neurosurg Psychiatry 2007;78(12):1365-72.

2. Ingall T, Asplund K, Mähönen M, Bonita R. A multinational comparison of subarachnoid hemorrhage epidemiology in the WHO MONICA stroke study. Stroke 2000:31:1054 .

3. Sandvei MS, Mathiesen EB, Vatten LJ, Muller TB, Lindekleiv H, Ingebritsen T, et al. Incidence and mortality of aneurismal subarachnoid hemorrhage in two Norwegian cohorts, 1984-2007. Neurology 2011; 77:1833 .

4. Linn FH, Rinkel GJ, Algra A, van Gijn J. Headache characteristics in subarachnoid haemorrhage and benign thunderclap headache. J Neurol Neurosurg Psychiatry 1998;65:791-3.

5. Wijdicks EF, Kallmes DF, Manno EM, Fulgham JR, Piepgras DG. Subarachnoid hemorrhage: neurointensive care and aneurysm repair. Mayo Clin Proc 2005;80:550-9.

6. Rinkel GJ, Djibuti M, Algra A, van Gijn J. Prevalence and risk of rupture of intracranial aneurysms: a systematic review. Stroke 1998;29:251-6.

7. Vernooij MW, Ikram MA, Tanghe HL, Vincent AJ, Hofman A, Krestin GP, et al. Incidental findings on brain MRI in the general population. N Engl J Med 2007;357:1821-8.

8. Juvela S, Porras M, Poussa K. Natural history of unruptured intracranial aneurysms: probability of and risk factors for aneurysm rupture. J Neurosurg 2000;93:379-87.

9. van Gijn J, Kerr RS, Rinkel GJ. Subarachnoid haemorrhage. Lancet 2007;369:306-18.

10. Broderick JP, Brott TG, Duldner JE, Tomsick T, Leach A. Initial and recurrent bleeding are the major causes of death following subarachnoid hemorrhage. Stroke 1994;25:1342.

11. Winn HR, Richardson AE, Jane JA. The long-term prognosis in untreated cerebral aneurysms: I. The incidence of late hemorrhage in cerebral aneurysm: a 10-year evaluation of 364 patients. Ann Neurol 1977;1:358.

12. Inagawa T, Kamiya K, Ogasawara H, Yano T. Rebleeding of ruptured intracranial aneurysms in the acute stage. Surg Neurol 1987;28:93.

13. Naidech AM, Janjua N, Kreiter KT, Ostapkovich ND, Fitzsimmons BF, Parra A, et al. Predictors and impact of aneurysm rebleeding after subarachnoid hemorrhage. Arch Neurol 2005;62:410.

14. Sevrain L, Rabehenoina C, Hattab N, Freger P, Creissard P. Les anevrismes a expression clinique grave d'emblee (grades IV et V de Hunt et Hess): Une serie de 66 cas. [Aneurysms with severe clinical manifestations (Hunt and Hess grade IV and V): a series of 66 cases]. Neurochirurgie 1990;36:287-96.

15. Disney L, Weir B, Grace M. Factors influencing the outcome of aneurysm rupture in poor grade patients: a prospective series. Neurosurgery 1988;23:1-9.

16. Kassell NF, Sasaki T, Colohan AR, Nazar G. Cerebral vasospasm following aneurismal subarachnoid hemorrhage. Stroke 1985;16:562.

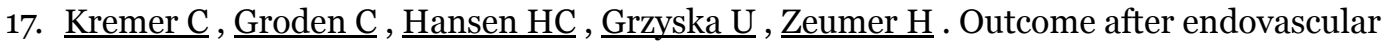
treatment of Hunt and Hess grade IV or V aneurysms: comparison of anterior versus posterior circulation. Stroke 1999 Dec;30(12):2617-22.

18. Sloan MA, Alexandrov AV, Tegeler CH, Spencer MP, Caplan LR, Feldmann E, et al. 
Assessment: transcranial Doppler ultrasonography: report of the Therapeutics and

Technology Assessment Subcommittee of the American Academy of Neurology. Neurology 2004;62:1468.

19. Krejza J, Kochanowicz J, Mariak Z, Lewko J, Melhem ER. Middle cerebral artery spasm after subarachnoid hemorrhage: detection with transcranial color-coded duplex US. Radiology 2005:236:621.

20. Zemke D, Farooq MU, Yahia AM, Majid A. Delayed ischemia after subarachnoid hemorrhage: result of vasospasm alone or a broader vasculopathy? Vasc Med 2007;12:243.

21. Frontera JA, Fernandez A , Schmidt JM , Claassen J , Wartenberg KE , Badjatia N , et al. Defining vasospasm after subarachnoid hemorrhage: what is the most clinically relevant definition? Stroke 2009 Jun;40(6):1963-8.

22. Schmidt JM, Fernandez A, Rincon F, Claassen J, Ostapkovich ND, Badjatia N, et al. Frequency and clinical impact of asymptomatic cerebral infarction due to vasospasm after subarachnoid hemorrhage. J Neurosurg 2008;109:1052-9.

23. De Devene C, Van Aken J, Decruyenaere J, Struys M, Colardyn F. Jugular bulb oximetry: review on a cerebral monitoring techniqueActa Anaesthesiol Belg 1998; 49(1):21-31.

24. Heran NS, Hentschel SJ, Toyota BD. Jugular bulb oximetry for prediction of vasospasm following subarachnoid hemorrhage. Can J Neurol Sci 2004 Feb;31(1):80-6.

25. Schaffranietz L, Heinke W. The effect of different ventilation regimens on jugular venous oxygen saturation in elective neurosurgical patients. Neurol Res 1998;20Suppl 1:S66-70.

26. Fandino J, Stocker R, Prokop S, Trentz O, Inhof HG. Cerebral oxigenation and systemic trauma related factors determining neurological outcome after brain injury. J Clin Neurosci 2000 May;7(3):226-33.

27. Thiagarajan A, Goverdhan PD, Chari P, Somasunderam K, Holzschuh M, Bein T, et al. The effect of hyperventilation and hyperoxia on cerebral venous oxygen saturation in patients with traumatic brain injury. Anest Analg 1998 Oct;87(4):850-3.

28. Suzuki H, Sato S, Suzuki Y, Takekoshi K, Ishihara N, Shimoda S. Increased endothelin concentration in CSF from patients with subarachnoid hemorrhage. Acta Neurol Scand 1990;81:553-4.

29. Masaoka H, Suzuki R, Hirata Y, Emori T, Marumo F, Hirakawa K. Raised plasma endothelin in aneurismal subarachnoid haemorrhage. Lancet 1989;2:1402.

30. Ziv I, Fleminger G, Dyaldetti R, Achiron A, Melamed E, Sokolovsky M. Increased plasma endothelin-1 in acute ischemic stroke. Stroke 1992;23:1014-6.

31. Kraus GE, Bucholz RD, Yoon KW, Knueffer MM, Smith KR. Cerebrospinal fluid endothelin-1 and endothelin-3 levels in normal and neurosurgical patients: A clinical study and literature review. Surg Neurol 1991;35:20-9.

32. Hamann G, Isenberg E, Strittmatter M, Schimrigk K. Absence of elevation of big endothelin in subarachnoid hemorrhage. Stroke 1993;24:383-6.

33. Fujimori A, Yanagisawa M, Saito A, Goto K, Masaki T, Mima T, et al. Endothelin in plasma and cerebrospinal fluid of patients with subarachnoid haemorrhage. Lancet 1990;336:633.

34. Yamaji T, Johshita H, Ishibashi M, Takaku F, Ohno H, Suzuki N, et al. Endothelin family in human plasma and cerebrospinal fluid. J Clin Endocrinol Metab 1990;71:1611-5.

35. Hunt WE, Hess RM. Surgical risc as related to time of intervention in the repair of 
intracranial aneurysms. Journal of Neurosurgery 1968 Jan;28(1):14-20.

36. Teasdale G, Jennett B. Assesment of coma and impaired consciousness. Lancet 1974;2:814 .

37. Teasdale G, Jennett B. Assessment and prognosis of coma after head injury. Acta Neurochir (Wien) 1976;34:45-55.

38. Vergouwen MDI, Vermeulen M, Gijn JV, Rinkel GJE, Wijdicks EF, Muizelaar JP, et al. Definition of delayed cerebral ischemia after aneurismal subarachnoid hemorrhage as an outcome event in clinical trials and observational studies.Stroke 2010;41:2391-5.

39. Toffaletti JG. Blood lactate: biochemistry, laboratory methods, and clinical interpretation. Crit Rev Clin Lab Sci 1991;28:253-68.

40. Jennett B, Bond M. Assessment of outcome after severe brain damage. Lancet 1975;1:480-4.

41. Rankin L. Cerebral vascular accidents in patients over the age of 60. II. Prognosis. Scott Med J 1957;2:200 -15.

42. van Swieten JC, Koudstaal PJ, Visser MC, Schouten HJ, van GJ. Interobserver agreement for the assessment of handicap in stroke patients. Stroke 1988;19:604-7.

43. Banks JL, Marotta CA . Outcomes validity and reliability of the modified Rankin scale: implications for stroke clinical trials: a literature review and synthesis. $\underline{\text { Stroke }} 2007$ Mar;38(3):1091-6.

44. Kozniewska E, Michalik R, Rafalowska J, Gadamski R, Walski M, Frontczak-Baniewicz M, et al. Mechanisms of vascular dysfunction after subarachnoid hemorrhage. J Physiol Pharmacol 2006;57(Suppl 11):145-60.

45. Stein SC, Levine JM, Nagpal S, LeRoux PD. (2006) Vasospasm as the sole cause of cerebral ischemia: how strong is the evidence? Neurosurg Focus 2006;21:E2.

46. Weidauer S, Vatter H, Beck J, Raabe A, Lanfermann H, Seifert V, Zanella F. Focal laminar cortical infarcts following aneurismal subarachnoid haemorrhage. Neuroradiology 2008;50:1-8.

47. Ng WH, Moochhala S, Yeo TT, Ong PL, Ng PY. Nitric oxide and subarachnoid hemorrhage: elevated level in cerebrospinal fluid and their implications. Neurosurgery 2001;49:622-7.

48. Romano JG, Rabinstein AA, Arheart KL, Nathan S, Campo-Bustillo I, Koch S, et al. Microemboli in aneurismal subarachnoid hemorrhage. J Neuroimaging 2008;18:396401.

49. Juvela S. Plasma endothelin concentrations after aneurysmal subarachnoid haemorrhage. J Neurosurg 2000;92:390-400.

50. Menon DK, Day D, Kuc RE, Downie AJ, Chatfield DA, Davenport AP. Arteriojugular endothelin-1 gradients in aneurysmal subarachnoid haemorrhage. Clin Sci (Lond) 2002;suppl48:399S.

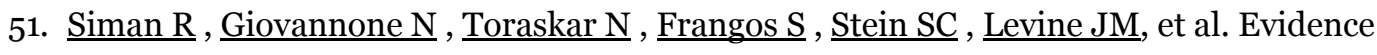
that a panel of neurodegeneration biomarkers predicts vasospasm, infarction, and outcome in aneurismal subarachnoid hemorrhage. PLoS One 2011;6:12.

52. Mascia L, Fedorko L, Stewart DJ, Mohamed F, terBrugge K, RanieriVM, et al. Temporal relationship between endothelin-1 concentrations and cerebral vasospasm in patients with aneurismal subarachnoid hem- orrhage. Stroke 2001;32:1185-90.

Table 1. Comparison of patients operated on after a ruptured and nonruptured cerebral 
aneurysm.

patients with a

ruptured cerebral

aneurysm and SAH

$\mathrm{N}=23$ (56.1\%) patients with a

nonruptured

aneurysm

$\mathrm{N}=18$ (43.9\%)

Mann-

Whitney

test

Age (median, range) 52 (26-71)

$55(40-68)$

$\mathrm{P}=$

0.486

Gender

male (\%)

female (\%)

$521.7 \%$

$1878.3 \%$

$633 \cdot 3 \%$

$1266.7 \%$

$\mathrm{X}^{2}$ test

$\mathrm{P}=$

0.406

Number of

aneurysms

$1(\%)$

$16(69.6 \%)$

$1583.3 \%$

$\mathrm{X}^{2}$ test

$7(30.4 \%)$

$316.7 \%$

$\mathrm{P}=$

$>1(\%)$

0.131

Mean arterial

pressure

before (mean, SD)

$82,049,744$

during

$96,789,195$

after

$99,5712,197$

the operation

(mmHg)

T test

$\mathrm{P}=$

78,17 10,037

o,886

$90,3310,082$

$99,6314,560$

$\mathrm{P}=$

o,661

$\mathrm{P}=$

0,551
Nimodipine

16

Tiopental (mg)

729

13

(N)

12

440

T test

$\mathrm{P}=$

0.054

$\chi^{2}$ test

$\mathrm{P}=$

0.735
Time to awake after general anesthesia (hours)
3.6

2

T test

$\mathrm{P}=$

0.014 
Time to extubation

(hours)

11.2

5

T test

$\mathrm{P}=$

0.010

Clinical suspicion of cerebrovascular

$1460.9 \%$

$\chi^{2}$ test

spasm

$738.9 \%$

, $\mathrm{P}=$

0.279

Motoric deficit

mild

2

significant

2

3

2

$\chi^{2}$ test

$\mathrm{P}=$

significant

0.696

Rankin score

0.390 .839

0.330 .594

T test

(mean, SD)

0.383

4.740 .541

4,670.485

T test

GOS (mean, SD)

$\mathrm{P}=$

0.683

GOS, Glasgow outcome scale; P, statistical probability; SAH, subarachnoid hemorrhage; SD, standard deviation.

Table 2. Potential biomarkers compared between the group of patients with a favorable and unfavorable neurologic outcome.

\section{Outcome}

\begin{tabular}{|c|c|c|c|c|c|c|c|}
\hline & \multicolumn{3}{|c|}{$\begin{array}{l}\text { Neurologic } \\
\text { defects }\end{array}$} & \multicolumn{3}{|c|}{$\begin{array}{l}\text { Without } \\
\text { neurologic } \\
\text { impairment }\end{array}$} & \multirow{2}{*}{$\begin{array}{l}\text { Statistics } \\
\\
\mathrm{Z} \quad \mathrm{P}\end{array}$} \\
\hline & $\mathbf{C}$ & $\begin{array}{l}\text { 25. } \\
\text { P. }\end{array}$ & $\begin{array}{l}75 \cdot \\
\mathbf{P} .\end{array}$ & $\mathbf{C}$ & $\begin{array}{l}\mathbf{2 5} \\
\mathbf{P}\end{array}$ & $\begin{array}{l}75 . \\
\mathbf{P}\end{array}$ & \\
\hline $\begin{array}{l}\text { Endothelin } 1 \text { in artery next } \\
\text { morning }(\mathrm{fmol} / \mathrm{mL})\end{array}$ & 0,08 & 0,05 & 0,14 & 0,07 & 0,05 & 0,13 & $-0,1920,848$ \\
\hline $\begin{array}{l}\text { Endothelin } 1 \text { in vein next morning } \\
(\mathrm{fmol} / \mathrm{mL})\end{array}$ & 0,07 & 0,04 & 0,13 & 0,13 & 0,04 & 0,32 & $-1,3090,190$ \\
\hline $\begin{array}{l}\text { Endothelin 1veno arterial } \\
\text { difference next morning (fmol/L) }\end{array}$ & $-0,02$ & $2-0,05$ & 0,03 & 30,03 & $-0,02$ & 0,18 & $-2,1220,034$ \\
\hline $\begin{array}{l}\mathrm{pCO}_{2} \text { in jugular vein before } \\
\text { aneurismal clamping }(\mathrm{kPa})\end{array}$ & 6,0 & 5,3 & 6,5 & 6,4 & 6,0 & 7,3 & $-1,9600,050$ \\
\hline $\begin{array}{l}\mathrm{pCO}_{2} \text { in jugular vein } 5 \text { minutes } \\
\text { after aneurismal clamping }(\mathrm{kPa})\end{array}$ & 6,0 & 5,2 & 6,5 & 6,5 & 6,0 & 6,9 & $-2,1960,028$ \\
\hline
\end{tabular}


$\mathrm{pCO}_{2}$ in artery 30 minutes after aneurismal clamping $(\mathrm{kPa})$

$4,5 \quad 4,1 \quad 5,1 \quad 4,8 \quad 4,7 \quad 5,3 \quad-2,0570,040$

$\mathrm{pCO}_{2}$ in jugular vein 30 minutes after aneurismal clamping $(\mathrm{kPa})$

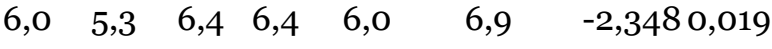

$\mathrm{pCO}_{2}$ in artery after arrival in ICU

$(\mathrm{kPa})$

$\begin{array}{lllllll}4,4 & 4,3 & 4,8 & 5,2 & 4,7 & 5,5 & -2,3400,019\end{array}$

$\mathrm{pCO}_{2}$ in jugular vein after arrival in ICU $(\mathrm{kPa})$

$$
5,6 \quad 5,2 \quad 5,9 \quad 6,2 \quad 5,7 \quad 6,7 \quad-2,0650,039
$$

$\mathrm{C}$, median; ICU, intensive care unit; $\mathrm{P}$, statistical probability; $\mathrm{pCO}_{2}$, partial pressure of carbon dioxide; Z,Mann Whitney test value.

Table 3. Correlation between lactate, $\mathrm{pCO}_{2}$ in arterial and jugular vein blood and GCS and Hunt Hess before operation and GCS score each hour after the operation.

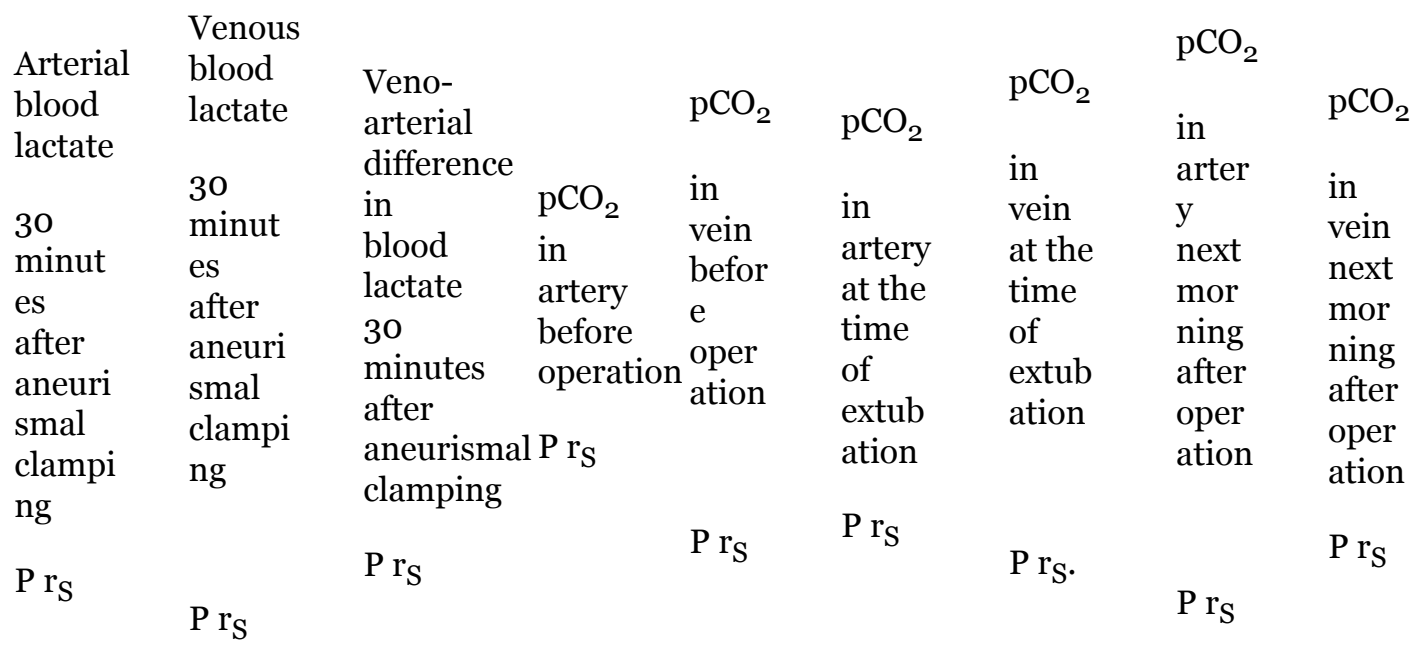

Before operation

\begin{tabular}{|c|c|c|c|c|c|c|c|c|c|}
\hline GSC & $\begin{array}{l}, 465 \\
-, 117\end{array}$ & $\begin{array}{l}, 146 \\
-, 231\end{array}$ & $\begin{array}{l}, 001 \\
-, 516^{* * *}\end{array}$ & $\begin{array}{l}, 058 \\
, 298\end{array}$ & $\begin{array}{l}, 130 \\
, 240\end{array}$ & $\begin{array}{l}, 512 \\
, 105\end{array}$ & $\begin{array}{l}\text {,103 } \\
, 258\end{array}$ & $\begin{array}{l}, 345 \\
, 151\end{array}$ & $\begin{array}{l}\text {, } 06 \\
\text {,29c }\end{array}$ \\
\hline $\begin{array}{l}\text { Hunt } \\
\text { Hess }\end{array}$ & $\begin{array}{l}\text {,908 } \\
, 019\end{array}$ & $\begin{array}{l}, 516 \\
, 104\end{array}$ & $\begin{array}{l}, 009 \\
, 403^{* * *}\end{array}$ & $\begin{array}{l}, 081 \\
-, 276\end{array}$ & $\begin{array}{l}, 057 \\
-, 299\end{array}$ & $\begin{array}{l}, 014 \\
-, 381^{*}\end{array}$ & $\begin{array}{l}, 005 \\
-, 432^{* * *}\end{array}$ & $\begin{array}{l}, 052 \\
-, 306\end{array}$ & $\begin{array}{r}, 01 \\
-36\end{array}$ \\
\hline
\end{tabular}

Hours after operation

\begin{tabular}{|c|c|c|c|c|c|c|c|c|c|}
\hline GSC & ,935 & 606 & ,036 & ,950 & ,892 & 993, & 903 & 923 & 90\& \\
\hline 1 &,- 013 &,- 083 &,$- 328^{*}$ &,- 010 &,- 022 &,- 001 & ,020 &,- 016 & ,01c \\
\hline $2_{2}^{\text {GSC }}$ & $\begin{array}{l}, 180 \\
-, 214\end{array}$ & $\begin{array}{l}, 106 \\
-, 256\end{array}$ & $\begin{array}{l}, 315 \\
-, 161\end{array}$ & $\begin{array}{l}, 337 \\
-, 154\end{array}$ & $\begin{array}{l}\text {,962 } \\
\text {, } 0088\end{array}$ & $\begin{array}{l}, 888 \\
, 023\end{array}$ & $\begin{array}{l}379 \\
, 141\end{array}$ & $\begin{array}{l}, 549 \\
-, 096\end{array}$ & '911 \\
\hline
\end{tabular}




\begin{tabular}{|c|c|c|c|c|c|c|c|c|c|}
\hline $3^{\text {GSC }}$ & $\begin{array}{l}, 373 \\
-, 143\end{array}$ & $\begin{array}{l}, 186 \\
-, 211\end{array}$ & $\begin{array}{l}, 061 \\
-, 296\end{array}$ & $\begin{array}{l}, 260 \\
, 180\end{array}$ & $\begin{array}{l}, 311 \\
, 162\end{array}$ & $\begin{array}{l}, 913 \\
-, 018\end{array}$ & $\begin{array}{l}, 868 \\
, 027\end{array}$ & $\begin{array}{l}, 639 \\
-, 076\end{array}$ & $\begin{array}{r}, 98 \\
, 016\end{array}$ \\
\hline $\begin{array}{l}\text { GSC } \\
4\end{array}$ & $\begin{array}{l}, 676 \\
-, 067\end{array}$ & $\begin{array}{l}, 368 \\
-, 144\end{array}$ & $\begin{array}{l}, 024 \\
-, 353\end{array}$ & $\begin{array}{l}, 151 \\
, 228\end{array}$ & $\begin{array}{l}\text {,110 } \\
\text {,253 }\end{array}$ & $\begin{array}{l}, 014 \\
, 380^{*}\end{array}$ & $\begin{array}{l}, 014 \\
, 381^{*}\end{array}$ & $\begin{array}{l}, 540 \\
, 098\end{array}$ & $\begin{array}{l}385 \\
, 139\end{array}$ \\
\hline $\begin{array}{l}\text { GSC } \\
5\end{array}$ & $\begin{array}{l}, 253 \\
-, 183\end{array}$ & $\begin{array}{l}, 106 \\
-, 256\end{array}$ & $\begin{array}{l}, 046 \\
-, 314^{*}\end{array}$ & $\begin{array}{l}, 263 \\
, 179\end{array}$ & $\begin{array}{l}, 044 \\
, 316^{*}\end{array}$ & $\begin{array}{l}, 025 \\
, 350^{*}\end{array}$ & $\begin{array}{l}, 026 \\
, 348^{*}\end{array}$ & $\begin{array}{l}\text {,206 } \\
\text { 201 }\end{array}$ & $\begin{array}{l}, 06 ; \\
, 285\end{array}$ \\
\hline${ }^{\text {GSC }}$ & $\begin{array}{l}, 227 \\
-, 193\end{array}$ & $\begin{array}{l}, 088 \\
-, 270\end{array}$ & $\begin{array}{l}, 036 \\
-, 329 *\end{array}$ & $\begin{array}{l}\text {,268 } \\
\text {,177 }\end{array}$ & $\begin{array}{l}\text {,079 } \\
\text { 277 }\end{array}$ & $\begin{array}{l}, 011 \\
, 392^{*}\end{array}$ & $\begin{array}{l}, 039 \\
, 324^{*}\end{array}$ & $\begin{array}{l}\text {,075 } \\
, 281\end{array}$ & $\begin{array}{r}, 0 \\
, 311\end{array}$ \\
\hline $7^{\text {GSC }}$ & $\begin{array}{l}, 305 \\
-, 164\end{array}$ & $\begin{array}{l}, 128 \\
-, 242\end{array}$ & $\begin{array}{l}, 032 \\
-, 335^{*}\end{array}$ & $\begin{array}{l}, 099 \\
, 261\end{array}$ & $\begin{array}{l}, 034 \\
, 331^{*}\end{array}$ & $\begin{array}{l}, 027 \\
, 345^{*}\end{array}$ & $\begin{array}{l}, 020 \\
, 363^{*}\end{array}$ & $\begin{array}{l}, 080 \\
, 277\end{array}$ & $\begin{array}{r}, 0: \\
, 33 c\end{array}$ \\
\hline $8^{\text {GSC }}$ & $\begin{array}{l}, 248 \\
-, 184\end{array}$ & $\begin{array}{l}\text {,084 } \\
-, 273\end{array}$ & $\begin{array}{l}, 013 \\
-, 387^{*}\end{array}$ & $\begin{array}{l}, 063 \\
\text {,293 }\end{array}$ & $\begin{array}{l}, 030 \\
, 338^{*}\end{array}$ & $\begin{array}{l}, 027 \\
, 346^{*}\end{array}$ & $\begin{array}{l}, 014 \\
, 381^{*}\end{array}$ & $\begin{array}{l}, 023 \\
, 355^{*}\end{array}$ & $\begin{array}{r}, 01 \\
, 40:\end{array}$ \\
\hline $\begin{array}{l}\text { GSC } \\
9\end{array}$ & $\begin{array}{l}, 525 \\
-,, 102\end{array}$ & $\begin{array}{l}, 260 \\
-, 180\end{array}$ & $\begin{array}{l}, 025 \\
-, 349^{*}\end{array}$ & $\begin{array}{l}\text {,123 } \\
\text { 245 }\end{array}$ & $\begin{array}{l}, 023 \\
, 354^{*}\end{array}$ & $\begin{array}{l}, 008 \\
, 407^{* * *}\end{array}$ &, 007 & $\begin{array}{l}, 002 \\
, 463^{* *}\end{array}$ & $\begin{array}{r}, 01 \\
, 436\end{array}$ \\
\hline $\begin{array}{l}\text { GSC } \\
10\end{array}$ & $\begin{array}{l}, 516 \\
-104\end{array}$ & $\begin{array}{l}, 257 \\
-, 181\end{array}$ & $\begin{array}{l}, 027 \\
-, 345^{*}\end{array}$ & $\begin{array}{l}, 116 \\
, 249\end{array}$ & $\begin{array}{l}, 024 \\
, 353^{*}\end{array}$ & $\begin{array}{l}, 008 \\
, 407^{* * *}\end{array}$ & $\begin{array}{l}, 010 \\
, 399^{* * *}\end{array}$ & $\begin{array}{l}, 003 \\
, 448^{* * *}\end{array}$ & $\begin{array}{r}, 01 \\
, 396\end{array}$ \\
\hline $\begin{array}{l}\text { GSC } \\
11\end{array}$ & $\begin{array}{l}, 629 \\
-, 078\end{array}$ & $\begin{array}{l}, 318 \\
-, 160\end{array}$ & $\begin{array}{l}, 016 \\
-, 374\end{array}$ & $\begin{array}{l}, 098 \\
, 262\end{array}$ & $\begin{array}{l}, 017 \\
, 371^{*}\end{array}$ & $\begin{array}{l}, 004 \\
, 436^{* * *}\end{array}$ & $\begin{array}{l}, 006 \\
425^{* * *}\end{array}$ & $\begin{array}{l}, 002 \\
, 461^{* *}\end{array}$ & $\begin{array}{r}, 01 \\
, 43\end{array}$ \\
\hline $\begin{array}{l}\text { GSC } \\
12\end{array}$ & $\begin{array}{l}, 652 \\
-, 072\end{array}$ & $\begin{array}{l}, 335 \\
-, 154\end{array}$ & $\begin{array}{l}, 016 \\
-, 374\end{array}$ & $\begin{array}{l}\text {,222 } \\
, 195\end{array}$ & $\begin{array}{l}, 038 \\
, 326^{*}\end{array}$ & $\begin{array}{l}, 005 \\
, 431^{* * *}\end{array}$ & $\begin{array}{l}, 006 \\
, 423^{* * *}\end{array}$ & $\begin{array}{l}, 003 \\
, 447^{* *}\end{array}$ & $\begin{array}{r}, 01 \\
, 42 c\end{array}$ \\
\hline $\begin{array}{l}\text { GSC } \\
13\end{array}$ & $\begin{array}{l}, 580 \\
-, 089\end{array}$ & $\begin{array}{l}, 287 \\
-, 170\end{array}$ & $\begin{array}{l}, 017 \\
-, 369^{*}\end{array}$ & $\begin{array}{l}, 177 \\
, 215\end{array}$ & $\begin{array}{l}, 027 \\
, 345^{*}\end{array}$ & $\begin{array}{l}, 007 \\
, 417^{* * *}\end{array}$ & $\begin{array}{l}, 006 \\
421^{* * *}\end{array}$ & $\begin{array}{l}, 002 \\
, 476^{* *}\end{array}$ & $\begin{array}{r}, 01 \\
, 435\end{array}$ \\
\hline $\begin{array}{l}\text { GSC } \\
14\end{array}$ & $\begin{array}{l}\text {,634 } \\
\text {,077 }\end{array}$ & $\begin{array}{l}, 338 \\
-, 154\end{array}$ & $\begin{array}{l}, 025 \\
-, 350\end{array}$ & $\begin{array}{l}\text {,197 } \\
\text {,205 }\end{array}$ & $\begin{array}{l}, 042 \\
, 319^{*}\end{array}$ & $\begin{array}{l}, 016 \\
, 373^{*}\end{array}$ & $\begin{array}{l}, 015 \\
, 376^{*}\end{array}$ & $\begin{array}{l}, 005 \\
, 434^{* *}\end{array}$ & $\begin{array}{r}, \text { or } \\
, 415\end{array}$ \\
\hline $\begin{array}{l}\text { GSC } \\
15\end{array}$ & $\begin{array}{l}, 766 \\
-, 048\end{array}$ & $\begin{array}{l}, 420 \\
-, 129\end{array}$ & $\begin{array}{l}, 015 \\
-, 376^{*}\end{array}$ & $\begin{array}{l}, 266 \\
, 178\end{array}$ & $\begin{array}{l}, 033 \\
, 334^{*}\end{array}$ & $\begin{array}{l}, 011 \\
, 395^{*}\end{array}$ & $\begin{array}{l}, 007 \\
, 415^{* * *}\end{array}$ & $\begin{array}{l}, 005 \\
, 434^{* *}\end{array}$ & $\begin{array}{l}, 00 \text {. } \\
445\end{array}$ \\
\hline $\begin{array}{l}\text { GSC } \\
16\end{array}$ & $\begin{array}{l}, 420 \\
-, 129\end{array}$ & $\begin{array}{l}, 197 \\
-, 206\end{array}$ & $\begin{array}{l}, 031 \\
-, 338^{*}\end{array}$ & $\begin{array}{l}\text {,135 } \\
\text {,237 }\end{array}$ & $\begin{array}{l}, 040 \\
, 323^{*}\end{array}$ & $\begin{array}{l}, 009 \\
, 403^{* * *}\end{array}$ & $\begin{array}{l}, 001 \\
488^{* * *}\end{array}$ & $\begin{array}{l}, 001 \\
, 491^{* *}\end{array}$ & $\begin{array}{r}, \text { Or } \\
, 517\end{array}$ \\
\hline
\end{tabular}




\begin{tabular}{|c|c|c|c|c|c|c|c|c|c|}
\hline $\begin{array}{l}\text { GSC } \\
17\end{array}$ & $\begin{array}{l}, 403 \\
-, 134\end{array}$ & $\begin{array}{l}, 211 \\
-, 200\end{array}$ & $\begin{array}{l}, 070 \\
-, 286\end{array}$ & $\begin{array}{l}, 169 \\
, 219\end{array}$ & $\begin{array}{l}\text {,088 } \\
\text {,270 }\end{array}$ & $\begin{array}{l}, 036 \\
, 328^{*}\end{array}$ & $\begin{array}{l}, 004 \\
, 436^{* *}\end{array}$ & $\begin{array}{l}, 002 \\
466^{* *}\end{array}$ & $\begin{array}{r}, \mathrm{or} \\
, 46\end{array}$ \\
\hline $\begin{array}{l}\text { GSC } \\
18\end{array}$ & $\begin{array}{l}, 332 \\
-, 155\end{array}$ & $\begin{array}{l}, 155 \\
-, 226\end{array}$ & $\begin{array}{l}, 052 \\
-, 305\end{array}$ & $\begin{array}{l}, 297 \\
, 167\end{array}$ & $\begin{array}{l}, 148 \\
, 230\end{array}$ & $\begin{array}{l}, 124 \\
, 244\end{array}$ & $\begin{array}{l}, 004 \\
436^{* *}\end{array}$ & $\begin{array}{l}, 005 \\
, 427^{* *}\end{array}$ & $\begin{array}{r}, \text { or } \\
, 536\end{array}$ \\
\hline $\begin{array}{l}\text { GSC } \\
19\end{array}$ & $\begin{array}{l}, 642 \\
-, 075\end{array}$ & $\begin{array}{l}, 519 \\
-, 104\end{array}$ & $\begin{array}{l}, 446 \\
-, 122\end{array}$ & $\begin{array}{l}\text {,537 } \\
\text {,099 }\end{array}$ & $\begin{array}{l}, 398 \\
, 136\end{array}$ & $\begin{array}{l}, 055 \\
, 301\end{array}$ & $\begin{array}{l}, 009 \\
403^{* * *}\end{array}$ & $\begin{array}{l}, 001 \\
, 485^{* * *}\end{array}$ & $\begin{array}{r}, \text { or } \\
\text {,48 }\end{array}$ \\
\hline $\begin{array}{l}\text { GSC } \\
20\end{array}$ & $\begin{array}{l}, 573 \\
-, 091\end{array}$ & $\begin{array}{l}, 359 \\
-, 147\end{array}$ & $\begin{array}{l}, 116 \\
-, 249\end{array}$ & $\begin{array}{l}, 263 \\
, 179\end{array}$ & $\begin{array}{l}, 201 \\
, 204\end{array}$ & $\begin{array}{l}, 025 \\
, 350^{*}\end{array}$ & $\begin{array}{l}, 007 \\
, 416^{* *}\end{array}$ & $\begin{array}{l}, 002 \\
, 461^{* * *}\end{array}$ & $\begin{array}{r}, \text { or } \\
\text {, 48 }\end{array}$ \\
\hline $\begin{array}{l}\text { GSC } \\
21\end{array}$ & $\begin{array}{l}, 358 \\
-, 147\end{array}$ & $\begin{array}{l}, 203 \\
-, 203\end{array}$ & $\begin{array}{l}, 135 \\
-, 238\end{array}$ & $\begin{array}{l}, 137 \\
, 237\end{array}$ & $\begin{array}{l}\text {,145 } \\
\text {,232 }\end{array}$ & $\begin{array}{l}, 074 \\
, 282\end{array}$ & $\begin{array}{l}, 016 \\
, 375^{*}\end{array}$ & $\begin{array}{l}, 008 \\
, 407^{* *}\end{array}$ & $\begin{array}{r}, \text { or } \\
, 451\end{array}$ \\
\hline $\begin{array}{l}\text { GSC } \\
22\end{array}$ & $\begin{array}{l}, 294 \\
-, 168\end{array}$ & $\begin{array}{l}, 187 \\
-, 210\end{array}$ & $\begin{array}{l}, 293 \\
-, 168\end{array}$ & $\begin{array}{l}\text {,207 } \\
\text {,201 }\end{array}$ & $\begin{array}{l}, 071 \\
, 285\end{array}$ & $\begin{array}{l}, 030 \\
, 340 *\end{array}$ & $\begin{array}{l}\text {,004 } \\
\text {,437 }\end{array}$ & $\begin{array}{l}, 005 \\
, 431^{* * *}\end{array}$ & $\begin{array}{r}\text {, Or } \\
, 474\end{array}$ \\
\hline $\begin{array}{l}\text { GSC } \\
23\end{array}$ & $\begin{array}{l}, 313 \\
-, 162\end{array}$ & $\begin{array}{l}, 168 \\
-, 220\end{array}$ & $\begin{array}{l}, 125 \\
-, 244\end{array}$ & $\begin{array}{l}\text {,201 } \\
\text { 204 }\end{array}$ & $\begin{array}{l}, 071 \\
, 285\end{array}$ & $\begin{array}{l}, 032 \\
, 336^{*}\end{array}$ & $\begin{array}{l}, 005 \\
429^{* *}\end{array}$ & $\begin{array}{l}, 009 \\
, 403^{* *}\end{array}$ & $\begin{array}{r}\text {, Or } \\
\text {, } 472\end{array}$ \\
\hline $\begin{array}{l}\text { GSC } \\
24\end{array}$ & $\begin{array}{l}, 446 \\
-, 122\end{array}$ & $\begin{array}{l}, 246 \\
-, 185\end{array}$ & $\begin{array}{l}, 081 \\
-, 275\end{array}$ & $\begin{array}{l}, 134 \\
, 238\end{array}$ & $\begin{array}{l}, 061 \\
, 295\end{array}$ & $\begin{array}{l}, 021 \\
, 360^{*}\end{array}$ & $\begin{array}{l}, 003 \\
, 452^{* * *}\end{array}$ & $\begin{array}{l}, 006 \\
, 425^{* * *}\end{array}$ & $\begin{array}{r}, \text { or } \\
, 46 !\end{array}$ \\
\hline $\begin{array}{l}\text { GSC } \\
48\end{array}$ & $\begin{array}{l}, 878 \\
, 025\end{array}$ & $\begin{array}{l}, 779 \\
-, 045\end{array}$ & $\begin{array}{l}, 032 \\
-, 335^{*}\end{array}$ & $\begin{array}{l}, 171 \\
, 218\end{array}$ & $\begin{array}{l}, 064 \\
, 292\end{array}$ & $\begin{array}{l}, 072 \\
, 284\end{array}$ & $\begin{array}{l}, 017 \\
, 371^{*}\end{array}$ & $\begin{array}{l}, 011 \\
, 394^{*}\end{array}$ & , OO: \\
\hline $\begin{array}{l}\text { GSC } \\
72\end{array}$ & $\begin{array}{l}, 877 \\
, 025\end{array}$ & $\begin{array}{l}, 792 \\
-, 043\end{array}$ & $\begin{array}{l}, 039 \\
-, 324^{*}\end{array}$ & $\begin{array}{l}\text {,197 } \\
\text {,206 }\end{array}$ & $\begin{array}{l}, 057 \\
, 299\end{array}$ & $\begin{array}{l}, 044 \\
, 316^{*}\end{array}$ & $\begin{array}{l}, 006 \\
, 422^{* * *}\end{array}$ & $\begin{array}{l}, 003 \\
, 449^{* * *}\end{array}$ & $\begin{array}{r}, \text { or } \\
, 52<\end{array}$ \\
\hline
\end{tabular}

GCS, Glasgow Coma Score; Hunt Hess, Hunt Hess score; P, statistical probability; $\mathrm{pCO}_{2}$, partial pressure of carbon dioxide; $\mathrm{r}_{\mathrm{S}}$, Spearman's correlation coefficient.

** Correlation is significant at the 0.01 level

* Correlation is significant at the 0.05 level

Table 4. Correlation between endothelin-1 and lactate concentrations.
ALL PATIENTS
$\mathrm{r}_{\mathrm{S}} \quad \mathrm{P}$

Endothelin-1 in arterial blood before the operation and 
lactate in arterial blood before the operation

Endothelin-1 in arterial blood before the operation and

lactate in arterial blood 5 minutes after aneurismal clamping

,484, 001

Endothelin-1 in arterial blood before the operation and

lactate in jugular vein blood 5 minutes after aneurismal clamping

,479,002

Endothelin-1 in arterial blood before the operation and

lactate in arterial blood 30 minutes after aneurismal clamping

,476, 002

Endothelin-1 in arterial blood before the operation and

lactate in jugular vein blood 30 minutes after aneurismal clamping

,465, 002

Endothelin-1 venoarterial concentration difference before the operation

and

lactate venoarterial concentration difference 30 minutes after aneurismal

$-, 449,003$ clamping

Endothelin-1 in artery next day after the operation and arterial lactate after the operation at arrival in ICU

,536,000

Endothelin-1 in artery next day after the operation and jugular vein lactate after the operation at arrival in ICU

\section{PATIENTS WITH RUPTURED ANEURYSM}

Endothelin-1 in arterial blood before the operation and Endothelin-1 in arterial blood during induction of anesthesia,

Lactate venoarterial concentration difference before the operation

Endothelin-1 in jugular vein 30 minutes after aneurismal clamping and arterial blood lactate on the day after the operation

Endothelin-1 in jugular vein blood 30 minutes after aneurismal clamping and lactate in jugular vein blood on the day after the operation

ICU, intensive care unit; P, statistical probability; $\mathrm{r}_{\mathrm{S}}$, Spearman's correlation coefficient.

Jelena Radonic (corresponding author)

Department of Anesthesiology, Reanimatology and Intensive Care of Neurosurgical Patients

Anesthesiology, Reanimatology and Intensive Care

University Hospital Centre Zagreb

Kispaticeva 12, 10000 Zagreb, Croatia

Phone: (+385) 912346584

E-mail: jelenaradonic@yahoo.com 
Article printed from Signa Vitae: http://www.signavitae.com

URL to article: http://www.signavitae.com/2015/12/testing-of-potentialbiomarkers-of-cerebral-ischemia-and-vasospasm-in-patients-with-cerebralaneurysm-surgery/

Copyright (C) 2015 Signa Vitae. All rights reserved. 